\title{
MARX, DISCOURSE THEORY AND POLITICAL ANALYSIS: NEGOTIATING AN AMBIGUOUS LEGACY
}

\begin{abstract}
This article argues that "post-Marxist" or "poststructuralist discourse theory" represents a complex deconstruction of the Marxist tradition of social and political theory. Focussing on three ontological positions in Marx's texts - the ontologies of human alienation, praxis, and production - the article shows how this approach repeats and transforms the rich tradition of Marxist thinking so as to elaborate a novel approach to social and political analysis. This claim is built around the idea that discourse is best conceptualized as an "articulatory practice", whose elements are both linguistic and non-linguistic in character, and whose products are finite relational orders, including social institutions and economic processes. The result is (1) a shift away from economic determinism and class reductionism to a relational account of social and political forms; (2) the development of an anti-essentialist and anti-reductionist account of political identities, which emerge in a dialectical tension with incomplete processes of identification, and (3) a particular understanding of the subject and agency in political theory, which grounds a different account of political practices. The article also (4) sets out the methodological implications of post-Marxist discourse theory, which is focussed on the articulation of different logics of critical explanation, before (5) exploring the role of critique and normativity in this approach, which are conceptualised as continuous, immanent and complex.
\end{abstract}

\section{KEYWORDS}

Discourse, post-Marxism, articulatory practices, subjectivity, political identities, logics of critical explanation

$* * *$

It is widely acknowledged that various species of discourse analysis play an important role in explaining diverse phenomena in the contemporary social sciences (e.g. Chouliaraki and Fairclough, 1999; Fairclough and Fairclough, 2013; van Dijk, 2008; Wodak, 2009). The variegation reflects the different theoretical origins of the approaches, as well as the multiple philosophical languages through which their starting assumptions have been transformed into viable research problematics. When introducing students to the theory and methods of discourse analysis, which have been developed at Essex university over the last three or four decades, I often use the acronym 'PDT' to name the approach, indicating that this sign can refer either to poststructuralist discourse theory or to political discourse theory, both of which provide significant inflections of the approach. But perhaps an even more accurate rendition of the signifier is post-Marxist discourse theory, for this captures the precise theoretical tradition from which this approach has emerged, and which thus provides the ontological co-ordinates that influence its concepts, focus, methods and ethico-political orientations.

More precisely, what has been termed the Essex School of Discourse Analysis, which has been inspired by Ernesto Laclau, Chantal Mouffe, Slavoj Žižek and others, draws on a range of critical theory - structuralism and poststructuralism, psychoanalysis and post-analytical philosophy - in order to deconstruct and develop the Marxist tradition of social and political theory. ${ }^{1}$ From this perspective, Marx bequeaths an ambiguous legacy. On the one hand, he 
widens our understanding of social relations to include economic processes and contradictions, while relating ideas and 'super-structural' forms to the 'material processes of production and reproduction'. Here the essential starting-point for our analysis of any phenomenon or process is the historically specific world of social relations in which human beings and things find themselves. Indeed, in this important respect, Marxists and postMarxists share the same materialist starting-point. On the other hand, however, he sometimes relapses into essentialist and idealist modes of theorising that short-circuit his relational imperative by positing universal causal laws and mechanisms, which compromise the contingencies and unexpected trajectories of historical evolution. For example, his endeavours to connect economic relations and processes (located in civil society) to political institutions and forms of consciousness are subverted by privileging the inherent, structural contradictions of civil society in class-divided societies. Arguments to link consciousness and social existence in a mutually constitutive relationship run aground when social existence is said to determine consciousness. In these and other formulations, Marx advances the idea that historical processes and social forms can be rationally grasped because both the concepts and the realities to which they refer are deemed to share a logical or conceptual form; this totalising conception of form yields an idealism that subsumes objectivity in a rational and all-encompassing system of intelligibility.

This article will explore the way in which a materialist conception of discourse can help to negotiate this ambiguous legacy in a productive way. It also sets out the implications of this conversation for rethinking key aspects of social and political theory, as well as the conduct of empirical research. I shall begin by setting out the main assumptions of PDT, which is built on an innovative conception of discourse. I then set out the consequences of this approach for our analysis of social and political phenomena. First, I argue that post-Marxism heralds a shift away from economic determinism and class reductionism to a fullyfledged relational account of social and political forms and, secondly, that this conception of discourse makes possible an anti-essentialist and anti-reductionist account of political identities, which emerge in a dialectical tension with incomplete processes of identification. Thirdly, this relational conception of discourse gives rise to a particular understanding of the subject and agency in political theory, which in turn grounds a different account of political practices. Both are then seen through the lens of the concept of hegemony. The fourth aspect of the article turns to the methodological implications of PDT, where I introduce the logics of critical explanation to counter claims that there is a methodological deficit in the approach. Finally, I turn to the role of critique and normativity, where I argue that PDT does not offer a value-free approach to social science, but advances a critical perspective that can elaborate alternative normative ideals.

\section{A MATERIALIST THEORY OF DISCOURSE}

I shall begin by sketching out the basic ontological assumptions of PDT, coupled with the ongoing endeavours to formalise the underlying methods and research strategies adopted by its supporters (Laclau and Mouffe, 2001; Glynos and Howarth, 2007). Central to the ontology of the Essex School is an innovative, if controversial, definition of discourse. In this view, discourse is best seen as both a general category that embraces all forms of social practice, and to conceptualise a particular sort of practice that is focussed more on the symbolic and representational dimensions of social practice. As a general category, the notion of discourse is used to claim that all social relations are symbolic and articulatory, that is, they involve the linking together of elements of many sorts - linguistic, physical, cultural, and so on - where 
such elements are assumed to be contingent entities that can be constructed and connected together in different ways. In its more narrow sense, discourse is taken to be those specific forms of language and symbolization (e.g. texts, documents, speeches, images, and so on) that represent and constitute social objectivity in various ways. Nevertheless, the line of demarcation between the general and linguistic dimensions of discourse is pragmatic and not 'super-hard', as Wittgenstein puts it in his critique of rule-following (e.g. Wittgenstein, 1967).

The connection between these core postulates and the writings of Marx and the Marxist tradition more generally is complex. This is not only because the proponents of PDT are intent on deconstructing some of the essentialist assumptions of the Marxist paradigm, but also because the Marxist paradigm is itself a heterogeneous tradition of thought and practice. In fact, it is this 'essential plurality' of the founding texts that renders it open to a deconstructive reading at all. More precisely, following Balibar and others, there are at least three ontological positions in Marx's fundamental texts (Balibar, 1995). First, in his early texts, there is 'an ontology of the human essence', where the latter finds itself alienated by various forms and forces, especially the products and processes of the labour process in capitalist society. Then there is 'an ontology of praxis', in which Marx disassociates certain elements of German idealism, such as the active role of the human subject, from their promise of bringing about a full representation of history and reality within selfconsciousness, and then rearticulates them a new and active materialism, which promises to exit the discourse of philosophy and theoretical reflection entirely. Finally, Marx offers 'an ontology of production' in which the course of history and its different social manifestations are predicated on the contradictions that arise from the inevitable growth of productive forces and the tensions that are created by the differential ownership of the means of production.

In his critique of Hegel (and idealist thinking in general), which in part draws upon Ludwig Feuerbach's critique of religion, the young Marx famously refuses the starting-point that begins with Spirit or the Idea and then charts its progressive unfolding and actualization in human self-consciousness and practice. Instead, he insists that 'the real alienation of man's essence' is found in those social forms and forces that effectively block the achievement of human objectification from the outside, which are especially evident in the social relations and practices involved in the production of objects and commodities in capitalist political economy (Marx, 1975). Reflecting its theoretical antecedents, this ontology thus presupposes a human essence, which is alienated by a range of social, political and economic conditions and processes, and that can only objectify itself in a society of free and spontaneous production, which he names communism. The antidote is a communist society - 'the solution to the riddle of history' - which requires 'the positive supersession of private property as human self-estrangement, and hence the true appropriation of the human essence though and for man' (Marx, 1975, p. 348).

Subsequently, Marx's critical engagement with Feuerbach's naturalistic inversion of the subject-predicate relation in religious discourse, reflected in his assertion that 'Man makes religion, religion does not make man' (Marx, 1975, p. 244), radicalizes the latter's conception of human activity and subjectivity. Materialism thus conceived is not just the passive contemplation or cognition of objects that are external to consciousness, but the active, human-sensuous and practical transformation of the world (Marx, 1975, p. 422). Marx also proposes to de-centre the human essence, so that instead of 'resolv[ing] the religious essence into the human essence', in which 'the human essence is [an] abstraction inherent in each single individual', Marx asserts that '[i]n its reality it [the human essence] is the ensemble of 
the social relations' (Marx, 1975, p. 423). Added to - and allied with - this philosophy of praxis is a concentration on class struggle as the driving motor of social and historical change (Marx \& Engels, 1997c).

Marx's final ontological position offers us a materialist conception of history, which underpins his critique of classical political economy. Here the aim is 'to reveal the economic law of motion of modern society', and thus the capitalist mode of production, is now concerned with the ways in which human beings produce and reproduce their conditions of existence in historically distinctive modes of production' (Marx, 1976, p. 92). Social and political forms, as well systems of human consciousness, are thus seen to reflect the objective structural dynamics of economic processes and logics, especially the contradictions between the inevitable growth of productive forces and the social relations of production that impede their expansionary tendency. Such contradictions yield a series of cascading crisis tendencies, such as the tendency of the rate or profit to fall as new forms of technology come to replace human labour power (which is the ultimate source of profit) that cannot be resolved within the pathologies of the capitalist system.

\section{MARX AND POSTSTRUCTURALIST DISCOURSE THEORY}

Aspects of each of these different ontological frameworks are articulated by the Essex school in the development of its own social ontology. In general, PDT shares with the Marxist tradition a conception of being that is resolutely relational, practical, and social. The emphasis on relationality is derived from Marx's opposition to abstract separations, such as the difference between the state and civil society in Hegel's Philosophy of Right, or his critique of ideas and philosophical abstractions in idealist philosophy in The German Ideology, which he claims gives rise to the conceit that 'consciousness can really flatter itself that it really represents something without representing something real; from now on consciousness is in a position to emancipate itself from the world and to proceed to the formation of "pure" theory, theology, philosophy, ethics etc.' (Marx and Engels, 1997a, p. 184). Instead, such divisions are related to the underlying divisions of labour in society, in particular the division between mental and manual labour, where Marx seeks to connect discrete elements and practices in wider systems of social relations.

In fact, the recourse to poststructuralist and post-analytical philosophy is prompted by the need to overcome the perceived short-circuiting of this emergent relationality in the Marxist tradition. And this arises because Marx's endeavours to develop a materialist conception of ideology and discourse, and indeed a differential account of the state and 'the economy', which is not reduced to underlying economic logics and processes, is often subverted by the positing of universal laws and logics that seem to transcend particular contexts. Central amongst the latter is the contradiction between the forces and relations of production, which is deemed to determine or causally shape other social processes, such as 'forms of consciousness', or legal institutions and political structures, regardless of their context and historical circumstance.

At the same time, Marx's emphasis on 'practice' in the 'Theses of Feuerbach' is also a strong feature of PDT. It will be recalled that discourse is conceptualized principally as an 'articulatory practice', which modifies and transforms the elements that are connected together in every practice. But it is also stressed that such elements include a disparate range of phenomena, including linguistic and non-linguistic objects, as well as cultural and natural 
things. Here, of course, it is true that in the move from an ontology of praxis to an ontology of production, Marx often downplayed or even erased the subjective and practical dimension of his materialism, so that creative human activity - including the affirmation of class struggle - was replaced by inexorable laws of historical evolution, which in turn were driven by objective dialectical contradictions inscribed into the very fabric of History itself. Indeed, it is this concern that animates Gramsci's endeavours to rethink historical materialism in terms of what he calls a 'philosophy of praxis', which is counter-posed to mechanical and deterministic interpretations of the Marxian heritage, evident in the second international and indeed in Marx (and Engels') original formulations (Gramsci, 1971).

So here again there is a point at which PDT seeks to deconstruct the totalizing objectivity of the Marxist paradigm by disclosing gaps and fissures in the structure of things, which under certain conditions enable (human) agency - and other forms of agency - to exert themselves. As against certain pictures in the Marxist paradigm, this is premised on the view that human beings and social structures are not fully constituted essences, but incomplete and historically contingent entities that can be constructed in different ways by different forces and processes. As Jacques Derrida shows in his deconstructive readings of various philosophical and literary texts in the metaphysical tradition, and which are used to rethink the Marxist conception of structure and totality, both conceptual and natural forms are always marked by a formlessness, in which an 'inside' is partly constituted by an 'outside'; the outside serves both as the limit of the inside and as its condition of impossibility (Derrida, 1997, pp. 30-65). cf. Staten, 1984). In this perspective, class struggles are but one form of collective social agency, which have contingent and historically specific conditions of existence, while class identities (just like others) are discursively constituted.

The stress on relationality and practice also brings out the social character of objects and processes in Marx's ontology. It is striking how Marx, even in his seemingly most mechanistic and deterministic accounts of history, stresses the social character of objects and processes in modern capitalist societies. For example, the circulation of commodities and the exchange of money are both understood as 'social relations' that are constitutive of different forms of subjectivity and indeed objective reality itself. Marx also insists on the social character of production and reproduction, as well as the social character of practice, discourse and language. In his words,

If, however, we bear in mind that the value of commodities has a purely social reality, and that they acquire this reality only in so far as they are expressions or embodiments of one identical social substance, viz., human labour, it follows as a matter of course, that value can only manifest itself in the social relation of commodity to commodity. (Marx, 1997b, p. 467).

In short, Marx and the Marxist tradition affirms the social character of being, both in its physical and cultural manifestations, while also insisting on their historical production.

Yet there are still tensions and paradoxes in this affirmation. Marx famously claimed that '[i]t is not the consciousness of men that determines their being', but he went on to add that it was 'their social being that determines their consciousness', in which social being is seemingly disconnected from consciousness and then privileged (Marx, 1997c, p. 425 My emphasis). Similarly, he relapses into essentialist (and thus idealist) modes of theorising when he argues, for instance, that legal relations and forms of consciousness have their roots in the material conditions of life, which can be combined together under the name of 'civil society', and that the anatomy of the latter is to be found in the laws of political economy. In such formulations, human consciousness can be reduced to more basic social processes and 
rationally grasped, because both the concepts and the realities to which they refer are deemed to share a logical or conceptual form. With this totalising conception of form a peculiar road to idealism beckons, as objects, their forms, and our conceptions of them, are said to partake of a similar essence that can be extracted and described.

Despite such tensions, however, it is important to recognise the important homologies between Marx and PDT with respect to their common commitment to the relational, practical, and social character of objects and subjects, processes and relations. In this sense, PDT is nothing more than the further development of the basic assumptions of Marxism, as new possibilities emergence from an immanent and deconstructive reading, though this will lead to different substantive implications and research strategies. Thus far, however, the discussion has remained at a very high level of abstraction, focussing on the philosophical points of connection between the two. So, if we are to develop the social and political implications of this general ontology, we must move to a more concrete set of formulations. And this brings us to social ontology and the primacy of politics.

\section{RETHINKING SOCIAL TOTALITIES: SOCIAL AND POLITICAL FORMS}

To begin with, I want to draw out the consequences of discourse theory for our understanding of social forms and structures. In this regard, the post-Marxist approach heralds a shift away from economic determinism (à la Marx) or a regional social ontology (à la Althusser and the early Poulantzas) to a full-fledged relational account of social forms, such as the state or different forms of governance (Althusser, 1970; 1971; Poulantzas, 1973; 1978). That is to say, instead of an economic determinism post-Marxist discourse theory draws on Gramsci and the later Poulantzas to conceptualise social formations as relational historical blocs or discursive formations.

In this model of social relations, the form and identity of the different elements or levels are predicated on the political exclusion of certain elements. In his Prison Notebooks, Gramsci embarked on a fundamental reworking of the Marxist concept of society, and his historicist approach both problematizes the orthodox relationship between state and civil society in Marxist theory, while introducing the idea of the 'integral state' to account for both the hegemonic and dictatorial aspects of political rule (Gramsci, 1971, pp. 169-70). The integral state thus leads to a general redefinition of the state in Marxist theory. Rather than just an instrument of class rule, Gramsci identifies it with 'the entire complex of practical and theoretical activities with which the ruling class not only justifies and maintains its dominance, but manages to win the active consent of those over whom it rules' (Gramsci, 1971, p. 244). Similarly, his concept of a 'historical bloc' articulates both structural and superstructural elements of society - the 'decisive economic nucleus,' political society and civil society - as a 'unity of opposites and distincts' (Gramsci, 1971, p. 137). Historical blocs are thus configurations of related elements, although they are ultimately organized around a fundamental social class and a dominant mode of production. Ideological practices and discursive interventions are an integral and vital component in the production and reproduction of social formations.

Gramsci thus intimates a relational account of the social topography, which can overcome the essentialism and economic determinism of classical Marxism. Yet he still accepts the role of the 'decisive economic nucleus' and the logics of material production in explaining the emergence, character and function of the complex superstructures, and he appears to endorse 
an ultimate resolution of the core contradictions in capitalism and class-divided societies more generally in a socialist society where politics and division can ultimately be transcended. Such essentialist assumptions are challenged by the proponents of post-Marxist discourse theory. In this alternative picture, social formations do not contain an inviolable core that can be discerned and conceptualised, nor is any a priority accorded to economic factors in both accounting for the formation of historical blocs, or their everyday modus operandi. Expressed in the theoretical language of PDT, historical blocs are better understood as relational discursive formations, whose emergence and functioning are not determined or caused by underlying economic (or any other) logics. They are thus the products of political practices, which are accorded a primary role in this theoretical approach.

\section{THE PRIMACY OF POLITICS}

In fleshing out this primacy of politics, it is important to stress that social formations are welded together by hegemonic practices, which in this approach are made possible by the articulation of different demands and elements in a common project. It will be recalled that Gramsci argues that the maintenance of class rule should be explained though a reworked conception of hegemony. Hegemony is not identified with the political leadership of a certain class in a strategic alliance struggling for state power, as Lenin had argued, but involves the construction and dissemination of 'intellectual and moral leadership' throughout society (Gramsci, 1971, p. 57). It comprises a complex set of practices that are designed to win the active and passive consent of key social actors in a particular historical bloc, while securing the compliance and coercion of others. This means that hegemony is not to be identified with a narrow notion of domination and government, because his new 'general notion of State' includes 'elements which need to be referred back to the notion of civil society' (Gramsci, 1971, p. 263).

In developing Gramsci's ideas within the ontological framework of PDT, hegemonic projects are unified by the establishment of political frontiers that divide social relations and discursive spaces into opposed blocs of forces. And the drawing of political boundaries is conceptualized as the construction of antagonistic relations between differently positioned actors, which results in the creation of political frontiers that divide insiders from outsiders. The construction of social antagonisms is thus not an expression of underlying 'objective' contradictions, nor is it reducible to an essentialized class struggle, which is thus posited as the only driver of historical change. Instead, the latter involve the creation of equivalential relations between disparate and different demands, where the unity and meaning of the latter are predicated on the exclusion of a common other. Such equivalential operations intersect with logics of difference, whose rules and modes of operation are to disentangle equivalential demands and in a struggle to include them within the dominant discourses and social formations. Processes of institutionalization, co-option, mediation, and so forth are thus characteristic of the logic of difference. The conditions for such logics and practices are made possible by the relational and materialist character of discourse in PDT, where all elements are radically contingent entities that admit of different articulations in different contexts.

A further consequence of this conception of discourse makes possible an anti-essentialist and anti-reductionist account of social and political identities. For PDT, political identities are not given or primordial entities that reflect underlying dispositions or features. Nor can they be explained by the structural location of social actors in a particular mode of production or social formation. Instead, they are best viewed as social constructions that are fabricated by 
complex political practices of inclusion and exclusion. The idea that identities and interests are forged by political practices derives inter alia from the writings of Gramsci and Georges Sorel, for whom the creation of 'collective wills' and 'blocs' of forces could not be deduced from objective positionalities in the economic structure. Instead, as in the case of Gramsci, political identities had to be fashioned by 'organic intellectuals' and political parties, whose task was to elaborate new ideologies and various forms of 'common sense', so as to connect together dispersed wills and interests. Or, as in the case of Sorel, they had to be produced through the adoption of particular tactics and actions, such as the 'general strike', which often entailed the use of force and violence, and which in the case of Georges Sorel functioned as an active 'myth' that was essential in the creation of social cleavages dividing the proletariat from a decadent bourgeoisie (Sorel, 1999). From a discourse theory perspective, the creation of a political identity supposes the drawing of boundaries. Political identities are precarious and incomplete processes-in-formation, which emerge through - and are often in tension with - processes of identification. This brings us to the question of the subject in discourse theory.

The relational conception of discourse gives rise to a particular understanding of subjectivity and agency in political theory. Discourse theorist distinguish between what Michel Foucault has called subject positions within a discourse - places of enunciation that subjects can occupy in speaking, acting and thinking for instance - and a more radical notion of political subjectivity in which subjects are conceded the capacity to act or decide as they identify with new objects or discourses in particular circumstances (cf. Foucault, 1972; 1981). The condition of possibility for the latter form of subjectivity is the dislocation of sedimented structures or situations - the making visible of the void or undecidability at the heart of any social order, that is, in which the contingency of signifiers and meanings is disclosed by events and crises - that new forms of agency and subjectivity emerge. Moreover, rooted in psychoanalysis, and especially the work of Jacques Lacan, this approach is based on a conception of the human subject that is marked by a fundamental lack or void, which can never be sutured by any particular discourse (Laclau, 1990, pp. 210-11; 2005, pp. 114, 257).In short, then, it is the failure of structures to provide stable points from which to speak or act that opens the space for a more radical form of subjectivity in which agents or actors are literally 'compelled' to be free and identify with new possibilities (Laclau, 1990, pp. 6064). It is here that the logic of hegemony - the creation of linkages between struggles and demands, coupled with endeavours to create new forms of social order - can begin to take hold.

\section{THE PROBLEM OF METHOD: RESEARCH STRATEGIES}

The commitment to 'radical materialism' and the concept of hegemony captures the fundamental ontological import of discourse theory (Laclau and Mouffe, 1987). But it is often asserted that PDT suffers from grave methodological deficits that pertain to its alleged incapacity to explain phenomena, where explanation is usually couched in causal terms, and its inability to develop meaningful research strategies that can justify the accounts it puts forward. From this perspective, PDT can re-describe phenomena with its own categories, or at worst it can develop a 'grand theory' that pays little heed to the empirical world it is supposed to explain. In Logics of Critical Explanation, Jason Glynos and David Howarth have responded to these claims by arguing that retroduction offers us a distinctive form of explanation, while the articulation of logics provides the means to flesh out the content of such explanations (Glynos and Howarth, 2007). In addressing the problem of method, I shall endeavour to integrate these elements into my overall post-Marxist perspective. 
In general terms, this approach consists of five basic steps. Following Foucault, the first step of discourse analysis in PDT involves a careful and systematic problematization of a particular phenomenon, where the latter is related both to a particular field of academic questions, as well as the social and political issues that confront us in specific historical contexts (Foucault, 1984). Secondly, the form of explanation in this approach is retroductive, rather than just inductive or deductive. Developing insights from the American pragmatist Charles Sanders Peirce (1960), the explanatory task begins with an anomalous or wondrous phenomenon - which must be constructed as a tractable explanandum - that would be rendered intelligible were a putative explanans to hold. Ideally, a critical explanation dissolves the problem encountered in an academic framework or system of social relations, or at least makes the problem less unintelligible than it was at the start of the process.

Thirdly, the content of any putative explanans is couched in terms of logics, rather than laws, causal mechanisms, or contextual self-interpretations. Logics in this view are not objective causal patterns that are independent of an actor's meaning. Yet equally, while their discernment must take actors' own meanings into account, they do not simply reflect or transmit an actor's self-interpretations. Instead, our conception of a 'logic' is designed to capture the rules that govern a meaningful practice, where such rules are historical and mutable, as well as the conditions that make the operation of such rules possible. In general terms, the search for logics seeks to provide answers to various questions: What are the purposes, meanings, and effects of a discursive practice for an analyst? Or, to use Wittgenstein's terms, what is the 'essence' of a practice? More prosaically, what makes a practice work and continue to do so? (Glynos \& Howarth, 2007, pp. 134-5).

In this approach, it is possible to identify three types of logic in PDT. Social logics enable the researching subject to characterize social practices in different contexts by capturing their rules and elucidating the properties of the objects presupposed by the practice. They are thus multiple and contextual: there are as many logics as the various situations that an investigator explores. They may capture economic, social, cultural and political processes: a particular logic of competition or commodification, for example, or a specific logic of bureaucratization in a particular social context. Political logics enable the researcher to explain and potentially criticize the emergence and formation of a practice or regime. Of particular importance in this regard are the logics of equivalence and difference. As I have argued above, the former enable the research to grasp the way in which political frontiers are constructed via the hooking together of different social demands and identities, whilst the latter captures the way in which demands are negated, disarticulated, mediated and negotiated by various institutions. Politics thus discloses the contingent character of any practice or institution by showing the role of power and exclusion in its formation. Finally, fantasmatic logics provide the means to explain and potentially criticize the way subjects identify with and are gripped by ideological discourses (Glynos, 2001). The concept of ideology is here understood as a dimension of social relations, whose function involves the logic of concealing the contingency of social relations and naturalizing the relations of domination in discourses or meaningful practices. An important focus in this regard is on the production of certain objects or fantasmatic narratives, which structure the way different social subjects are attached to certain signifiers, and on the different types of 'enjoyment' subjects procure in identifying with discourses and believing things they do (Žižek, 1989; 1990).

It is clear, however, that any putative explanans expressed in these terms will encompass multiple logics that operate in a historically specific and heterogeneous set of social 
circumstances. And so questions arise about the process of constructing a potential explanation without subsuming the diversity of elements into a mono-causal pattern, while also avoiding the pitfalls of an eclectic approach that presents an incoherent narrative. The task of linking together multiple elements into an explanation thus forms the fourth step of the approach. It is here that the idea of discourse as an articulatory practice can be used as a methodological device to conceptualize the quilting together of various types and tokens of the different logics detected in a particular context, which are then set alongside the concrete social and historical circumstances that are in play. The result of this practice - hooking and modifying a rage of diverse elements into the moments of an explanation - would be a singular explanans that purports to explain a constructed explanandum (Glynos \& Howarth, 2007, pp. 180-81).

Linking together various elements and logics, located at varying degrees of abstraction and complexity, has a clear resonance with some of Marx's reflections on the method of political economy. For example, in his famous introduction to the Grundrisse, he defines the correct dialectical approach as proceeding from simple abstractions (such as the commodity in the capitalist mode of production) to the most concrete and complex descriptions of an investigated phenomenon or formation by systematically adding and integrating further determinations and specifications. To use terms associated with his approach, this means that a successful explanans involves the production of a synthesis comprising 'a rich totality of many determinations and relations', while its testing would focus on the extent to which the proto-explanation actually elucidates or resolves the various puzzles discerned in the problematization process (Marx, 1973, p. 100). Stripped of its essentialist assumptions, and thus the derivation or deduction of the concrete from the abstract, Marx's method is thus replicated and developed in the idea of an articulatory practice that couples and modifies multiple elements and logics.

\section{CRITIQUE AND NORMATIVITY}

I come finally to the question of critique, which is the fifth step of the method. The work of critique and evaluation in the 'logics approach' does not precede or follow after the tasks of characterization and explanation. Instead, the task of social criticism is internally connected to the related practices of problematization, characterization, and political engagement. In this view, proponents of PDT endeavour to steer a course between an unapologetic positivism, which denies any role for critique and value in scientific investigation (other than those values intrinsic to science itself), and a partisan approach that is prepared to compromise the virtues of scientific study - objectivity, impartiality, consistency, and so on - in the name of an explicit set of political commitments and values (cf. Herzog, 2016).

In relating critical issues to Marx and the Marxist tradition, we should begin by rehearsing the well-known fact that in addition to his appropriation of French socialism and British political economy, Marx was steeped in the tradition of German idealist philosophy. It is also evident that the latter was committed to the idea of 'critique', whether reflected in Kant's magisterial critiques of pure and practical reason, as well as his endeavours to determine the proper limits and character of judgment, or in Hegel's 'immanent critique' of natural consciousness or abstract right, for example, or indeed in Feuerbach's critique of Christianity or religion in general. Equally unsurprising, Marx offers us various conceptions of critique, which are related to the different themes and phases of his theoretical development. For example, his critique of Hegel's Philosophy of Right directly challenges the latter's doctrine of right and 
the state, as well as its implications for conceptualising the relationship between the state and class in a modern capitalist society. In other places, Marx's normative critique is directed at showing the failure of bourgeois society in actualising and realising its affirmed ideals, such as freedom, democracy and social justice. In Capital, by contrast, Marx's critique is directed both at a critical reading and reworking of classical political economy, where he unveils vital aporias in the key texts of classical political economy, as well as a critique of the very operation of capital, especially manifest in what he terms the 'fetishism of commodities' (Benhabib, 1986).

In order to characterise the way PDT approaches the task of critique and evaluation, one can position the approach along three axes: the continuous/discontinuous, the internal/external, and the simple/complex. Seen in these terms, the approach promulgated here is continuous, immanent and complex. It thus sees a direct connection between its explanations, and its political critiques and ethical judgements. Although the practice of critique, evaluation and even prescription is not logically entailed by objective, causal explanations, it still flows from the combination of its ontological commitments, processes of problematization, and the characterisations of the phenomena investigated, which in this view involves values and ethical orientations. Such characterizations imply that critique presupposes the endeavour to interpret social phenomena from within so to speak, where efforts are made to elucidate the rules and conditions that govern such processes and practices. Finally, given its ontological assumptions, the task of critique and evaluation is multi-dimensional: it is not only concerned with both critique and normative evaluation, but it focusses on a complex set of logics and practices, which are dispersed along various ontological dimensions, including social relations, political practices, and the interplay between the ideological and ethical dimensions of social life.

Expressed in more concrete terms, then, the practice of critique is designed to show the contingency and naturalization of sedimented relations and identities. This practice detects foregrounding the role of power in the formation of identities, where power involves the taking of decisions amongst possibilities. But it is also concerned to expose the foreclosures, dominations and exclusions that mark the historical and political constitution of such systems and relations in the first place, while simultaneously uncovering and developing alternative possibilities that have been excluded in their emergence and sedimentation. Such norms and values form the necessary background to any logic of critical investigation; they are reflected, for example, in commitments to the radicalization and pluralization of liberal democracy, but they are also developed and refined in the practice of characterization and criticizing particular practices and regimes of practice in specific contexts and conjunctures.

\section{CONCLUSION}

Proponents of poststructuralist or post-Marxist discourse theory are often accused of peddling an 'ex-Marxism' that severs its links with material reality and social structures, leaving it vulnerable to charges of relativism and voluntarism. However, I have argued that PDT represents a complex continuation and negotiation of the Marxist tradition, so that to use Derrida's terms it seeks to 'iterate' the latter's core concepts and logics, both repeating and transforming this rich and heterogeneous tradition of thinking. When a key dimension of discourse is conceptualized as an 'articulatory practice', whose elements and raw materials are both linguistic and non-linguistic in character, and whose products are finite relational orders that include social institutions and economic processes, then the upshot is a materialist 
approach that seeks to de-construct, de-essentialize and historicize the Marxist paradigm, but not transcend or abandon its founding assumptions.

\section{BIBLIOGRAPHY}

Althusser, L. (1969) For Marx, London: Verso.

Althusser, L. (1971) Lenin and Philosophy, and other essays, New York: Monthly Review Press.

Balibar, É. (1995) The Philosophy of Marx, London: Verso.

Benhabib, S. (1986) Critique, Norm and Utopia, New York: Columbia University Press.

Chouliaraki, L. and Fairclough, N. (1999) Discourse in Late Modernity, Edinburgh: Edinburgh University Press.

Derrida, J. (1997) Of Grammatology, Baltimore: Johns Hopkins Press.

Fairclough, I. and Fairclough, N. (2013) Political Discourse Analysis, London: Routledge. Foucault, Michel (1972) The Archaeology of Knowledge, London: Tavistock.

Foucault, Michel (1981) 'The Order of Discourse', in Robert Young (ed.), Untying the Text, London: Routledge, pp. 48-79.

Foucault, M. (1984b) Polemics, Politics and Problemizations: An Interview, in P. Rabinow (ed.) The Foucault Reader, Harmondsworth: Penguin.

Glynos, J. (2001) 'The grip of Ideology. A Lacanian Approach to the Theory of ideology', Journal of Political Ideologies, 6(2): 191-214.

Glynos, J. and Howarth, D. (2007) Logics of Critical Explanation in Social and Political Theory, Abingdon: Routledge, 2007.

Gramsci, A. (1971) Selections from Prison Notebooks. London: Lawrence and Wishart.

Herzog, B. (2016). Discourse Analysis as Immanent Critique. Possibilities and limits of normative critique in empirical discourse studies. Discourse \& Society, 27(3): 278292.

Howarth, D. (2013) Poststructuralism and After: Structure, Agency and Power. London: Palgrave.

Laclau, E. (1990) New Reflections on the Revolution of Our Time, London: Verso.

Laclau, E. (1996) Emancipation(s), London: Verso.

Laclau, E. (2005) On Populist Reason, London: Verso.

Laclau, E. and Mouffe, C. (1987) 'Post-Marxism without Apologies', New Left Review (166): 79-106.

Laclau, E. and Mouffe, C. (2001) Hegemony and Socialist Strategy: Towards a Radical Democratic Politics. Second Edition. London: Verso.

Marx, K. (1973) Grundrisse, Penguin Books: Harmondsworth.

Marx, K. (1975) Early Writings, Penguin Books: Harmondsworth.

Marx, K. (1976) Capital: Volume 1, Penguin Books: Harmondsworth.

Marx, K. and Engels, F. (1997a) The German Ideology, in McLellan, D. (ed), Karl Marx: Selected Writings, Second Edition, Oxford University Press: Oxford.

Marx, K. (1997b) Capital: Volume 1, in McLellan, D. (ed), Karl Marx: Selected Writings, Oxford University Press: Oxford.

Marx, K. (1997c) 'Preface to A Critique of Political Economy', in McLellan, D. (ed), Karl Marx: Selected Writings, Second Edition, Oxford University Press: Oxford.

Marx and Engels, F. (1997d) The Communist Manifesto, in McLellan, D. (ed), Karl Marx: Selected Writings, Oxford University Press: Oxford.

Peirce, C.S. (1960) Collected Papers, vols. 1 and 2, Cambridge, MA: The Belknap Press of Harvard University Press.

Poulantzas, N. (1973) Political Power and Social Class, London: Verso. 
Poulantzas, N. (1978) State, Power, Socialism, London: New Left Books.

Sorel, G. (1999) Reflections on Violence, Cambridge: Cambridge University Press.

Staten, H. (1984) Wittgenstein and Derrida, Lincoln: University of Nebraska Press. van Dijk, T. (2008) Discourse and Power, London: Palgrave.

Wittgenstein, L. (1967) Philosophical Investigations, Oxford: Blackwell.

Wodak, R. (2009) The Discourse of Politics in Action, London: Palgrave.

Žižek, S. (1989) The Sublime Object of Ideology, London: Verso.

Žižek, S. (1990) 'Beyond Discourse-Analysis', in E. Laclau, New Reflections on the Revolution of Our Time, London: Verso.

Žižek, S. (1999) The Ticklish Subject, London: Verso.

${ }^{1}$ See inter alia Howarth, 2013; Laclau and Mouffe, [1985] 2001; Laclau, 1990; 1996; 2005; Žižek, 1989, 1990, 1999. 